\title{
Kitchen Freedom
}

\section{Sandra Vida}

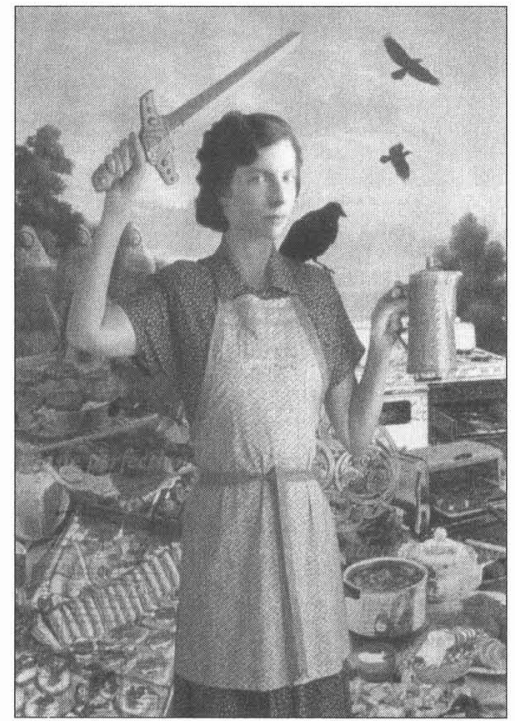

Spring (detail)

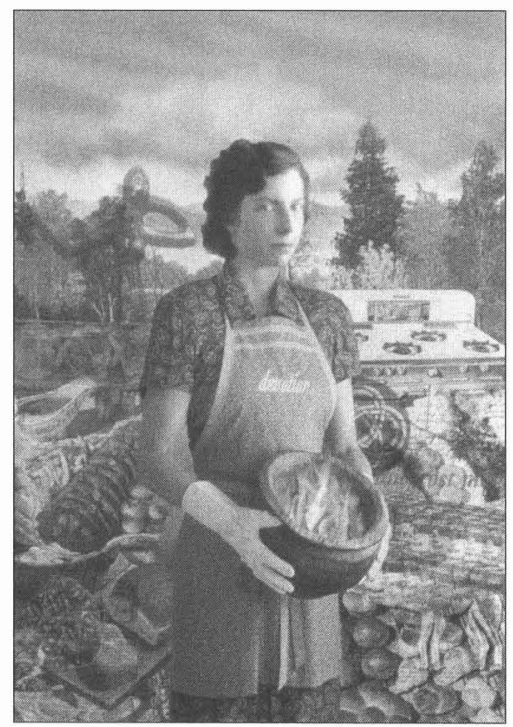

Autumn (detail)

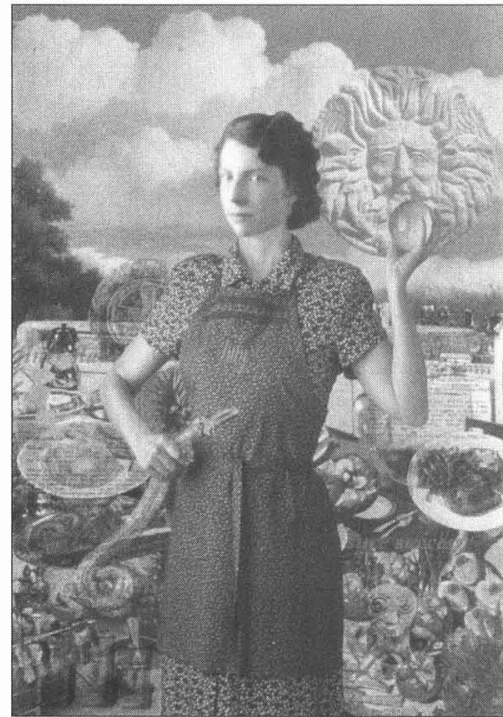

Summer (detail)

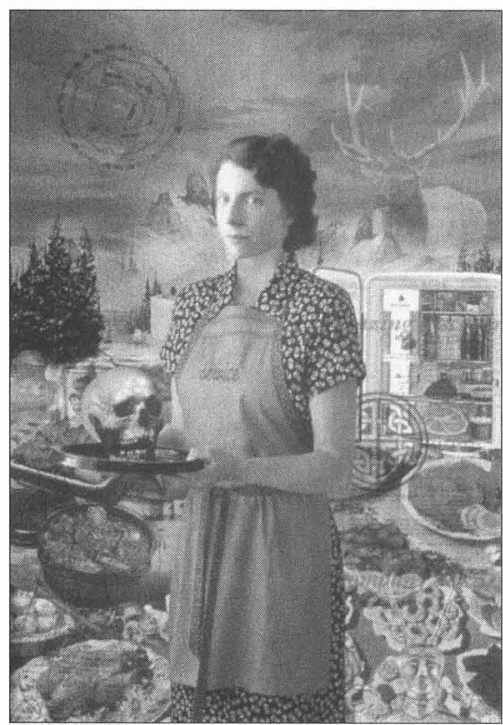

Winter (detail)

digital collages, $75 \times 100 \mathrm{~cm}$ each, from Kitchen Freedom installation, 2000 